\title{
Kapur-Toriello syndrome
}

INSERM

\section{Source}

INSERM. (1999). Orphanet: an online rare disease and orphan drug data base. Kapur-

Toriello syndrome. ORPHA:2328

Kapur-T oriello syndrome is an extremely rare syndrome characterized by facial

dysmorphism, severe intellectual deficiency, cardiac and intestinal anomalies, and growth retardation. 